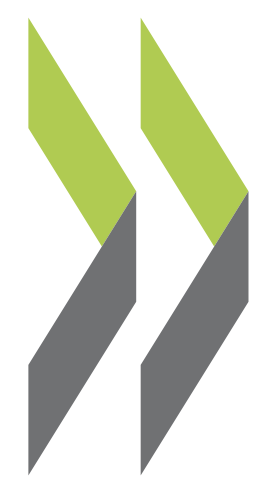

OECD Working Papers on Insurance and Private Pensions No. 14

\title{
Sovereign Wealth and Pension Fund Issues
}

\section{Adrian Blundell-Wignall,}

Yu-Wei Hu,

Juan Yermo 


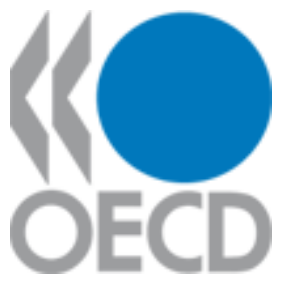

SOVEREIGN WEALTH AND PENSION FUND ISSUES

\author{
Adrian Blundell-Wignall, Yu-Wei Hu and Juan Yermo
}

January 2008

OECD WORKING PAPER ON INSURANCE AND PRIVATE PENSIONS

No. 14

Financial Affairs Division, Directorate for Financial and Enterprise Affairs

Organisation for Economic Co-operation and Development

2 Rue André Pascal, Paris 75116, France

www.oecd.org/daf/fin/wp 


\begin{abstract}
RÉSUMÉ
Sovereign Wealth and Pension Fund Issues.

Sovereign Wealth Funds (SWFs) are pools of assets owned and managed directly or indirectly by governments to achieve national objectives. These funds have raised concerns about: (i) financial stability, (ii) corporate governance and (iii) political interference and protectionism. At the same time governments have formed other large pools of capital to finance public pension systems, i.e. Public Pension Reserve Funds (PPRFs). SWFs are set up to diversify and improve the return on foreign exchange reserves or commodity revenue, and to shield the domestic economy from fluctuations in commodity prices. PPRFs are set up to contribute to financing pay-as-you-go pension plans. The total of SWF pools is estimated at around USD 2.6 trillion in 2006/7, and is getting bigger rapidly, owing to current exchange rate policies and oil prices. The total amount for PPRFs is even larger, around USD 4.4 trillion in 2006/7, if the US Trust Fund is included (USD 2.2 trillion if excluded). SWFs and PPRFs share some characteristics, hence give rise to similar concerns. However, their objectives, investment strategies, sources of funding and transparency requirements differ. There is concern about strategic and political objectives of SWFs, and their impact on exchange rates and asset prices. But SWFs also provide mechanisms for breaking up concentrations of portfolios that increase risk. Enhancing governance and transparency of SWFs is important, but such considerations have to be weighed against commercial objectives.
\end{abstract}

JEL codes: E58, G18, G23, G28

Keywords: pension funds, sovereign wealth funds, foreign reserves, asset management, governance

$* * * * *$

\title{
Problèmes soulevés par les fonds souverains et les fonds de pensions
}

Les fonds souverains sont des pools d'actifs détenus et gérés, directement ou indirectement, par des pouvoirs publics et répondant à des objectifs nationaux. Ces fonds suscitent des préoccupations en termes de: (i) stabilité financière, (ii) gouvernement d'entreprise et (iii) interférences politiques et protectionnisme. Parallèlement, les pouvoirs publics ont constitué de grands pools de capitaux destinés à financer les systèmes publics de retraite, les fonds de pension publics. Les fonds souverains sont constitués pour diversifier et améliorer la rentabilité des réserves de changes ou des revenus tirés des matières premières ainsi que pour protéger l'économie nationale des fluctuations des cours des matières premières. Les fonds de pension publics sont constitués pour contribuer au financement des plans de retraite par répartition. Le total des actifs des fonds souverains est estimé aux alentours de USD 2600 milliards en 2006/7, et il augmente rapidement, du fait des politiques actuelles de taux de change et des cours du pétrole. Le montant total des actifs des fonds de pension public est encore plus important, on l'estime en effet à quelque USD 4400 milliards pour 2006 si l'on y inclut le « US Trust Fund » (USD 2200 milliards autrement). Les fonds souverains et les fonds de pension publics ont des caractéristiques communes et, de ce fait, soulèvent des inquiétudes similaires. En revanche, leurs objectifs, leurs stratégies d'investissement, leurs sources de financement et leurs obligations en matière de transparence diffèrent. Les objectifs stratégiques et politiques des fonds souverains sont sources de préoccupation, de même que leur impact sur les taux de change et les prix des actifs. Cela étant, ils sont également assortis de mécanismes permettant de rompre les concentrations de portefeuilles qui ont pour effet d'accroître les risques. Il est important d'améliorer la gouvernance et la transparence des fonds souverains, mais ces considérations doivent être mises en balance avec les objectifs commerciaux.

Codes JEL : E58, G18, G23, G28

Mots-clés : fonds de pension, fonds souverains, réserves de change, gestion d'actif, gouvernance 


\section{Copyright OECD, 2008}

Applications for permission to reproduce or translate all, or part of, this material should be made to: Head of Publications Service, OECD, 2 rue André-Pascal, 75775 Paris Cédex 16, France. 


\title{
SOVEREIGN WEALTH AND PENSION FUND ISSUES
}

\author{
by Adrian Blundell-Wignall, Yu-Wei Hu and Juan Yermo ${ }^{1}$
}

\section{Introduction}

Sovereign Wealth Funds (SWFs) are pools of assets owned and managed directly or indirectly by governments to achieve national objectives. They may be funded by: (i) foreign exchange reserves; (ii) the sale of scarce resources such as oil; or (iii) from general tax and other revenue. There are a number of potential objectives of SWFs, which are not always easy to attribute to a particular fund; and some funds may have more than one of the distinguishable objectives. Some of these are: (i) to diversify assets; (ii) to get a better return on reserves; (iii) to provide for pensions in the future; (iv) to provide for future generations when natural resources run out; $(v)$ price stabilisation schemes; $(v i)$ to promote industrialisation; and (vii) to promote strategic and political objectives.

These funds have raised concerns about: (i) financial stability, (ii) corporate governance and (iii) political interference and protectionism.

At the same time governments have formed other large pools of capital, in particular to finance public pensions, which are generally referred to as Public Pension Reserve Funds (PPRFs). There are two such types of funds: those set up and owned directly by government (Sovereign Pension Reserve Funds, or SPRFs) and those belonging to the social security system (Social Security Reserve Funds, or SSRFs). SPRFs may be considered a type of SWF with a specific mandate to finance future public pension expenditures. On the other hand, not all SSRFs may be considered SWFs. Some are legally independent of government and their balances are not integrated for national accounting purposes into the government accounts.

This paper focuses primarily on the issues at the broad macro level. It also compares the possible effects of different kinds of pools of capital, depending on how they are formed and on their governance, rules and strategies. ${ }^{2}$

\section{Definition and examples of Sovereign Wealth and Pension Reserve Funds}

There is no single, widely accepted definition of SWFs and PPRFs. In this paper PPRFs are identified by their specific mandate to finance public pension systems.

1. A SWF is a fund set up to diversify and improve the return on foreign exchange reserves or commodity (typically oil) revenue, and sometimes to shield the domestic economy from (cycle inducing) fluctuations in commodity prices. As such most invest in foreign assets. This group (in

${ }^{1}$ Adrian Blundell-Wignall is Deputy Director in the OECD Directorate for Financial and Enterprise Affairs, and YuWei Hu and Juan Yermo are consultant and principal administrator, respectively, in the Financial Affairs Division in the same directorate. The opinions expressed and arguments employed herein are those of the authors and do not necessarily reflect the official views of the Organisation or of the governments of its member countries. The authors are solely responsible for any errors.

${ }^{2}$ A version of this paper served as background for discussion at the October 2007 meeting of the OECD Committee on Financial Markets and the December 2007 meeting of the OECD Working Party on Private Pensions. Other aspects related to SWFs have been addressed in other OECD Committees, in particular the Steering Group on Corporate Governance, the Working Group on Privatisation and Corporate Governance of StateOwned Assets, and the Investment Committee. 
order of size) includes the Abu Dhabi Investment Authority (ADIA), the Norway Government Pension fund - Global, the Government of Singapore Investment Corporation (GIC), the Kuwait Investment Authority (KIA), the Saudi Arabian Monetary Authority (SAMA), the China Investment Corporation (CIC), the Stabilisation Fund of the Russian Federation, Temasek Holdings (Singapore), The Reserve Fund of Libya, the Revenue Regulation Fund of Algeria, the Qatar Investment Authority (QIA), and many more. Where national resource funds are earmarked for particular regions, such as Canada's Alberta Heritage Savings Trust Fund, and the USA Alaska Permanent Fund, they are included as a SWF. Some of the above funds are set up to meet industrial objectives, such as regional development, as in Temasek.

2. Public Pension Reserve Funds (PPRFs) could be defined as funds set up by governments or social security institutions with the objective of contributing to financing the relevant pay-as-yougo pension plans. Based on this yardstick, two sub-categories of pension reserve funds can be identified:

i. The first type, Social Security Reserve Funds (SSRFs), is set up as part of the overall social security system, where the inflows are mainly surpluses of employee and/or employer contributions over current payouts, as well as, in some cases, topup contributions from the government via fiscal transfers and other sources. Among others, Denmark's Social Security Fund, Japan's Government Pension Investment Fund, and USA's Social Security Trust Fund fall within this category. These funds may be managed by the social security institution itself or an independent - often public sector - fund management entity. While most of these funds, like the social security system itself, fall under the government sector, there are some exceptions. For example, the Canada Pension Plan (CPP) reserve fund is legally independent of government. The CPP has no financial guarantee from government and relies solely on mandatory pension contributions and investment income from the reserve fund to finance pension benefits for Canadian citizens. In this sense, the CPP reserve fund may not be considered a SWF.

ii. The second type, Sovereign Pension Reserve Funds (SPRFs), refers to those funds which are established directly by the government (completely separated from the social security system), and its financial inflows are mainly from direct fiscal transfers from the government. Unlike the first type of reserve fund, those within this category have been set up by governments to meet future deficits of the social security system. Some are not allowed to make any payouts for decades. Examples include the Australian Future Fund, the New Zealand Superannuation Fund, the Irish National Pension Reserve Fund, the Norwegian Government Pension Fund, and the French Fonds de réserve pour les retraites. Some of these funds are sometimes treated as SWFs and indeed a few fit both definitions. For example, Government Pension Fund-Norway and Government Pension Fund-Global, both established in 2006, are the result of the re-structuring of the Norwegian pension reserve funds (formerly, the National Insurance Scheme Fund) and a SWF (formerly, the Government Petroleum Fund). The Government Pension FundGlobal (solely invested in foreign assets) has a mandate beyond financing pension expenditures, and is therefore classified as a SWF in this paper. 


\section{How large are global SWF \& PPRF markets?}

\section{SWFs}

Some funds are a mix of SWF and pension assets which belong to individuals, as in the GIC, which manages these and foreign exchange reserves for the Monetary Authority of Singapore (MAS). Korea's investment authority has a similar mix of assets to manage. For this reason we include both as SWFs rather than PPRFs.

\section{Figure 1. Sovereign wealth funds by size}

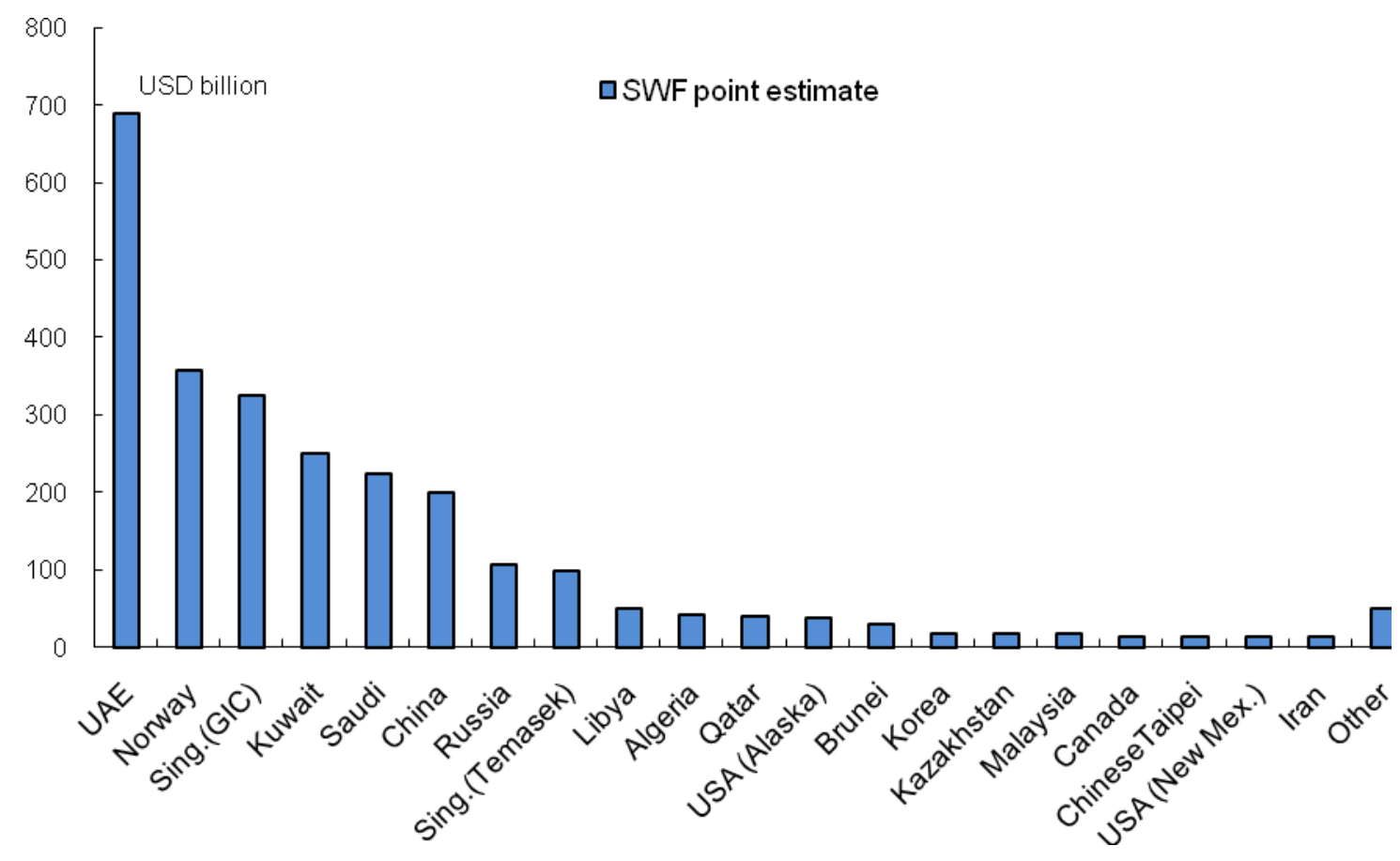

Note: In February 2008 the Stabilisation Fund of the Russian Federation was split into two separate funds (i.e. the reserve Fund and the National Wealth fund) while at the same time portion of this Fund was transferred to the Federal budget.

Source: Private sector market sources, central banks' balance sheets.

The size of the main SWFs are shown in Figure 1 and Table 1. At present, ADIA (UAE) is the largest, at $26.3 \%$ of the total, followed by Singapore's 2 funds at $16.2 \%$, the Norway Government Pension Fund Global at 13.6\%, the Kuwait Investment Authority at 9.5\%, the Saudi Arabian Monetary Authority (not foreign exchange reserves) at $8.6 \%$, and China Investment Corporation at 7.6\%.

Our estimate of total SWF pools is around USD 2.6 trillion, but they are getting bigger at a rate that is beginning to alarm some commentators. SWFs are likely to grow rapidly with the current configuration of foreign exchange policies, the relative weakness of the US dollar and the current oil price. For example, Chinese intervention policies are generating accelerating increases in reserves at present (a staggering USD 446 billion in the year to September 2007, versus USD 247 billion in the year to December 2006). China is beginning the process of transferring this money to its SWF (China Investment Corporation). So there is scope for rapid acceleration in these entities. 
Table 1. Sovereign wealth funds estimates

Assets under management in USD billion, various dates

\begin{tabular}{|c|c|c|c|c|c|c|c|}
\hline \multirow[b]{2}{*}{ Country } & \multirow[b]{2}{*}{ Fund, year established } & \multicolumn{3}{|c|}{$\begin{array}{l}\text { Estimates of assets under management (AuM) by } \\
\text { Sovereign Wealth Funds (SWF), according to } \\
\text { different sources }\end{array}$} & \multirow[b]{2}{*}{ Official } & \multirow[b]{2}{*}{$\begin{array}{c}\text { Range of } \\
\text { estimated AuM }\end{array}$} & \multirow{2}{*}{$\begin{array}{l}\text { Foreign } \\
\text { Exch. } \\
\text { Reserves }\end{array}$} \\
\hline & & Deutsche Bank & $\begin{array}{l}\text { Peterson } \\
\text { Institute }\end{array}$ & $\begin{array}{l}\text { Morgan } \\
\text { Stanley }\end{array}$ & & & \\
\hline UAE & Abu Dhabi Investment Authority, 1976 & 875 & 500 to 875 & 875 & & 500 to 875 & 48.5 \\
\hline Singapore & Gov. of Sing. Invest. Corp. (GIC), 1981 & 330 & 100 to 330 & 330 & & 100 to 330 & 164.9 \\
\hline Norway & Government Pension Fund - Global & 322 & 308 & & 357 & $308-357$ & 38.4 \\
\hline Saudi Arabia & Saudi Arabian Monet. Auth. ${ }^{1}$ & 300 & - & 300 & 225 & 225 to 300 & 33.8 \\
\hline Kuwait & Kuwait Invest. Auth. (KIA, 1953), & 250 & 213 & 70 & & 70 to 250 & 16.6 \\
\hline China & China Investment Corporation (CIC), $2007^{2}$ & 200 & - & 200 & & 200 & $1,528.2$ \\
\hline Russia & Stab. Fund of the Russian Fed. (SFRF), 2003 & 127 & 122 & - & & 32 to 127 & 483.2 \\
\hline Singapore & Temasek Holdings, 1974 & 108 & 108 & 100 & & 100 to 108 & 164.8 \\
\hline Libya & Reserve Fund & 50 & & & & 50 & na \\
\hline Qatar & Qatar Investment Authority, 2000 & 40 & 50 & 40 & & 40 to 50 & 9.9 \\
\hline Algeria & Revenue Regulation Fund & 25 & 43 & - & & 25 to 43 & na \\
\hline USA & Alaska Permanent Reserve Fund, 1976 & 40 & 40 & 39 & & 39 to 40 & 70.6 \\
\hline Brunei & Brunei Investment Authority (BIA), 1983 & 35 & 30 & 30 & & 30 to 35 & na \\
\hline Korea & Korean Invest. Corp. (KIC) & 20 & 20 & & & 20 & 261.4 \\
\hline Kazakhstan & National Oil Fund & 18 & 18 & & & 18 & 19.1 \\
\hline Malaysia & Khazanah Nasional & 18 & 18 & 17.7 & & 18 & 101.5 \\
\hline Canada & Alberta Heritage TF (1976) & 17 & & 13 & & 13 to 17 & 42.2 \\
\hline Chin. Taipei & National Stab. Fund & 15 & & 15 & & 15 & 2.7 \\
\hline USA & New Mex. SIO Trust Fund & 15 & & & & 15 & above \\
\hline Iran & FX Reserve Fund & 15 & & 8 & & 8 to 15 & na \\
\hline Other & & 50 & & & & 50 & \\
\hline TOTAL & (of above) & 2,870 & 2,274 & 2,038 & & $2,038-2,870$ & $2,985.8$ \\
\hline Memo items: & & & $\begin{array}{l}\text { World hedge } \\
\text { funds AuM incl. F- } \\
\text { of-F) }\end{array}$ & $\begin{array}{l}\text { OECD } \\
\text { pension } \\
\text { funds }\end{array}$ & & $\begin{array}{l}\text { World mutual } \\
\text { funds AuM }\end{array}$ & \\
\hline & & & 2,000 & 17,915 & & 21,765 & 5,200 \\
\hline
\end{tabular}

This table reflects the OECD definition of a SWF - it excludes Public Pension Reserve Funds, and excludes obvious overlaps (e.g. HK Monetary Authority using the GIC to invest).

1. The Saudi Arabian government is establishing a SWF using reserves held by the monetary authority and other government assets.

2. Assets previously held by China Huijin Investment Corporation (approximately USD 65 bn) are now integrated to those of CIC.

3. The official estimate of the Norwegian data (i.e. USD 357bn) refers to December 2007.

Source: Peterson Institute, Deutsche Bank, OECD, national sources. Data for worldwide mutual funds is from Investment Company Institute. Total pension fund data is from OECD Global Pensions Statistics Project.

Transfers to oil producers are also accelerating. At a (say) USD 70 oil price and say 85 million barrels per day consumption, the world is handing over revenue of over USD 2 trillion per annum. There are costs of producing oil, and some of the surplus is consumed - but the sums are very large indeed.

The total amount for PPRFs is an even larger USD 4.4 trillion as of 2006/7, if the US Trust Fund is included, some 53.9\% of the total. This reduces to USD 2.2 trillion if we exclude the US Trust Fund, on the grounds that the amount cannot ever be traded because it is a notional accounting figure (IOU number) based on accumulated surpluses lent to the government. The USD 2.2 trillion is shown in Figure 2. USD 1.2 trillion was accumulated by Japan's National Reserve Funds - accounting for $29.3 \%$ of the total; USD 228.7 billion by Korea, at about $5.5 \%$ of the total. 
Figure 2. Public Pension Reserve Fund (PPRF) assets by country, in USD billion

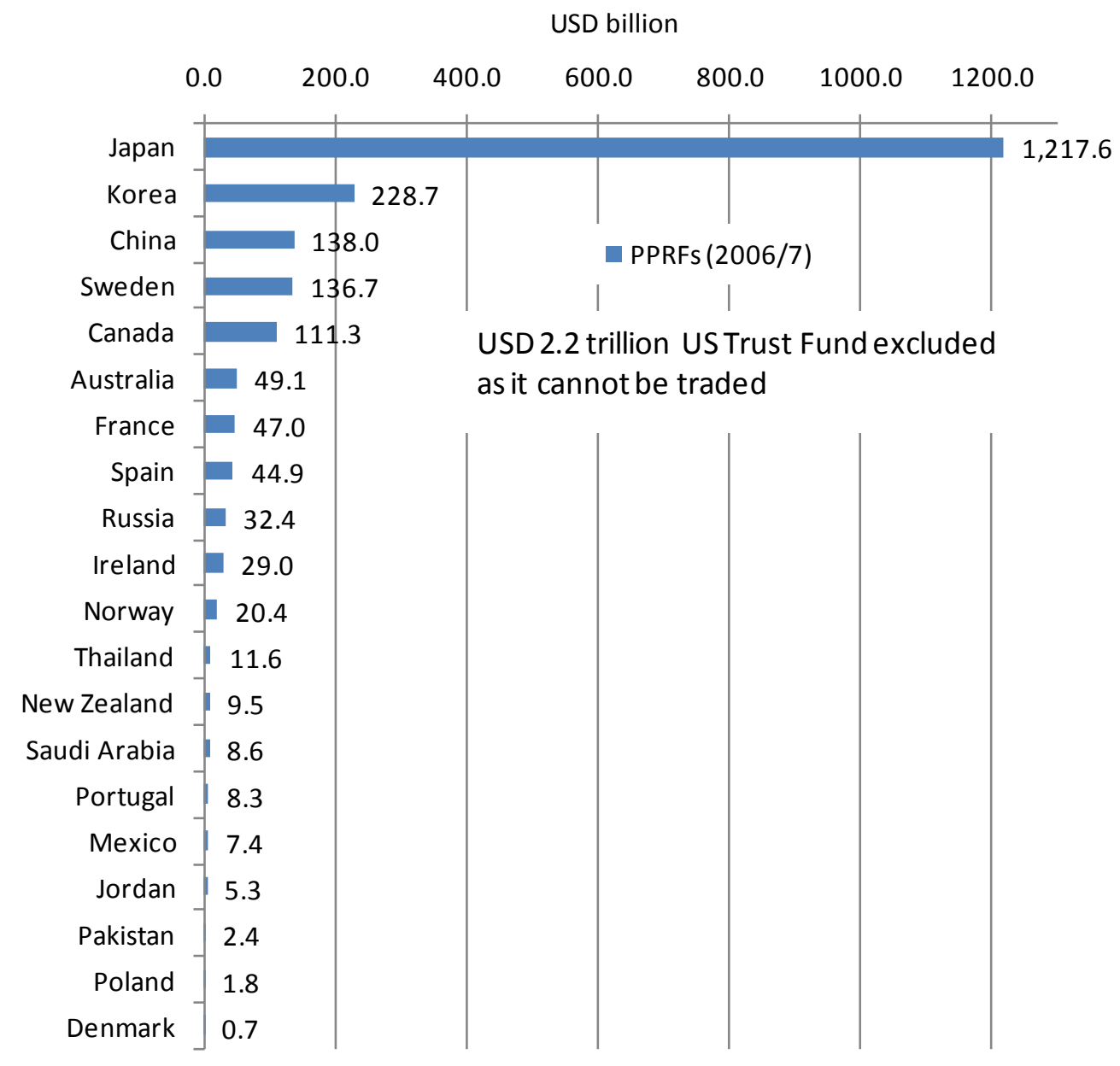

Source: OECD and national sources.

Some of the PPRFs, especially those of the sovereign (longer-run accumulation) kind, are relatively new. For example, Australia's Future Fund was established in 2006, New Zealand's Superannuation Fund was established in 2001, Russia's National Wealth Fund in 2008 and China's National Social Security Fund in 2001. Given their short history, their assets are smaller than those in the more mature funds. However, some of these funds are growing rapidly. For example, as of 2006, the Future Fund in Australia had assets equivalent to USD 13.6 billion, while this figure increased to USD 49.1 billion as of February 2008 .

In terms of total assets relative to the respective national economies (i.e. GDP), Table 2 shows that Sweden had the biggest system, i.e. $31.6 \%$ in 2007 . The other countries where pension reserve funds were significant relative to the economy include Japan (27.9\%) and Korea (23.9\%). On average, the ratio of OECD PPRFs assets to GDP was $15.0 \%$ in $2006 / 7$.

A large amount of PPRF assets have been also accumulated in non-OECD countries. For example, in 2007 China and Russia witnessed such assets at USD 138bn (94.6 bn plus 43.4 bn) and USD 32.4, respectively. In terms of the PPRFs assets to GDP ratio, Jordan had the largest value at $36.7 \%$. 
Table 2. Statistical summary of selected Public Pension Reserve Funds by region and type, 2006

\begin{tabular}{|c|c|c|c|c|c|}
\hline & Country & Name of the fund/institution & USD bn & $\%$ of total & $\%$ of GDP \\
\hline \multirow[t]{7}{*}{ OECD: SSRF } & Canada & Canada Pension Plan & 111.3 & 2.7 & 8.1 \\
\hline & Denmark & Social Security Fund & 0.7 & 0.0 & 0.2 \\
\hline & Japan & National Reserve Funds & $1,217.6$ & 29.3 & 27.9 \\
\hline & Korea & National Pension Fund & 228.7 & 5.5 & 23.9 \\
\hline & Mexico & IMSS Reserve & 7.4 & 0.2 & 0.9 \\
\hline & Spain & Fondo de reserva de la seguridad social & 44.9 & 1.1 & 3.7 \\
\hline & USA & Social Security Trust Fund & $2,238.5$ & 53.9 & 16.6 \\
\hline \multirow[t]{9}{*}{ OECD: SPRF } & Australia & Future Fund & 49.1 & 1.2 & 5.5 \\
\hline & France & fond de reserve des retraites' (FRR) & 47.0 & 1.1 & 1.9 \\
\hline & Ireland & National Pensions Reserve Fund & 29.0 & 0.7 & 11.5 \\
\hline & New Zealand & New Zealand Superannuation Fund & 9.5 & 0.2 & 7.8 \\
\hline & Norway & Government Pension Fund - Norway & 20.4 & 0.5 & 5.3 \\
\hline & Poland & Demographic Reserve Fund (DRF) & 1.8 & 0.0 & 0.6 \\
\hline & Portugal & Social Security Financial Stabilisation Fund & 8.3 & 0.2 & 4.3 \\
\hline & Sweden & National Pension Funds (AP1-AP4 and AP6) & 136.7 & 3.3 & 31.6 \\
\hline & OECD:Total & & $4,150.8$ & 100.0 & 15.0 \\
\hline \multirow[t]{5}{*}{ Non-OECD: SSRF } & China & National reserve funds & 94.6 & 57.7 & 3.1 \\
\hline & Jordan & Social Security Corporation & 5.3 & 2.7 & 36.7 \\
\hline & Pakistan & Employees' Old-Age Benefits & 2.4 & 1.2 & 1.8 \\
\hline & Saudi Arabia & General Organisation for Social Insurance & 8.6 & 4.3 & 2.4 \\
\hline & Thailand & Social Security Office & 11.6 & 5.9 & 5.6 \\
\hline \multirow[t]{3}{*}{ Non-OECD: SPRF } & China & National Social Security Fund & 43.4 & 26.4 & 1.4 \\
\hline & Russia & National Wealth Fund & 32.4 & 16.3 & 3.3 \\
\hline & Non-OECD:Total & & 198.2 & 100.0 & 4.2 \\
\hline
\end{tabular}

Notes: SPRF stands for Sovereign Pension Reserve Fund, and SSRF stands for Social Security Reserve Fund. For definitions see main text. Japan's National Reserve Funds reflect mainly assets managed by the Government Pension Investment Fund (GPIF). China's national reserve funds reflect mainly assets of the provincial and local social security funds.

\section{SWFs and PPRFs: similarities and differences}

SWFs and PPRFs share some similarities. Both are very large in terms of assets under management, and are autonomous and accountable only to governments or public sector institutions. Like SWFs, PPRFs are also increasingly investing abroad and moving into alternative assets (e.g. property, private equity and hedge funds). Hence the financial stability concerns raised over SWFs are also applicable to PPRFs.

However, there are still a number of discernable differences between SWFs and PPRFs.

1. The objectives of these funds are different. PPRFs serve as a long-term financing vehicle of public pensions and other related benefits, while SWFs are normally established to shield the domestic economy from fluctuations in commodity prices (e.g. oil) and to diversify foreign reserve holdings into higher return assets, among others. Hence, PPRFs manage assets to meet clearly defined liabilities, while SWFs tend to have broad objectives and are rarely assigned to meet specific government expenditures. For this same reason, the investment horizon of PPRFs tends to be better defined and longer than that of SWFs. Some PPRFs even have specific timeframes for drawing down funds and at least one (the Canadian one) aims to meet a funding target (the ratio of public pension asset to liabilities). Clear objectives and investment timeframes shed much clarity to the mission of PPRFs and are conducive to better governance and more efficient investment management.

2. In many countries PPRFs face strong pressures to invest their resources domestically and conservatively. This is more the case of PPRFs managed within the social security system. Three 
of the four largest PPRFs, the US Social Security Trust Fund, the Japanese GPIF, and the Korean National Pension Fund are largely (solely in the US case) invested in domestic government securities. In emerging markets, where institutional investors and capital markets are underdeveloped, it is sometimes felt that PPRFs should help promote domestic investment and financial sector development. These concerns contrast with those of SWFs which are by construction mainly or solely invested in foreign assets.

3. As noted earlier, SWFs and PPRFs have different sources of funding. SWFs are mainly financed by foreign exchange revenues on commodity exports and/or transfers of foreign reserves from the Central Bank. PPRFs, on the other hand, are more often financed via social security contributions or direct fiscal transfers from the government.

4. PPRFs may also raise issues concerning fiduciaries' responsibilities and of social ownership by pensioners of PPRF assets. Trustees may constrain what these funds can do and require greater transparency than is the case for SWFs. For example, most PPRFs have policies for socially responsible investments.

\section{SWFs and PPRFs' asset allocation across countries}

Consistent with this latter observation (point 4 above), we found it much easier to extract information about PPRF governance and asset allocations than we did for SWFs. It is extremely difficult to find information on actual SWF sizes and investment allocations. One concern about SWFs is that their governance, investment objectives and asset allocations may reflect strategic and political objectives. 
Table 3. Asset allocation information of PPRFs in 2006/7

In per cent of total asset allocations

\begin{tabular}{|c|c|c|c|c|c|c|c|}
\hline & & EQUITIES & BONDS & CASH & PROPERTY & $\begin{array}{l}\text { ALTERNATIVE } \\
\text { INV. }\end{array}$ & OTHER \\
\hline \multirow[t]{14}{*}{ OECD } & Australia & 25.6 & & 72.8 & \multirow{4}{*}{6.8} & \multirow{4}{*}{6.9} & 1.6 \\
\hline & Canada & 57.9 & 28.3 & 0.1 & & & 0 \\
\hline & Denmark & 0.7 & 26.4 & 67.0 & & & 5.9 \\
\hline & France & 64.5 & 33.5 & 1.2 & & & 0.8 \\
\hline & Ireland & 72.3 & 16.7 & 4.4 & \multirow[t]{2}{*}{1.4} & \multirow[t]{2}{*}{4.5} & \\
\hline & Japan & 37.3 & 62.7 & 0.0 & & & \\
\hline & Korea & 13.7 & 83.2 & 0.3 & \multirow{4}{*}{6.9} & \multirow[t]{2}{*}{2.5} & 0.3 \\
\hline & New & & & & & & \\
\hline & Zealand & 59.9 & 17.3 & & & \multirow[t]{2}{*}{10.8} & \multirow[t]{2}{*}{5.1} \\
\hline & Norway & 48.3 & 51.3 & 0.4 & & & \\
\hline & Portugal & 20.8 & 70.1 & 2.2 & \multirow[t]{4}{*}{3.6} & \multirow{4}{*}{3.8} & \multirow[t]{2}{*}{3.3} \\
\hline & Spain & 0.0 & 100.0 & & & & \\
\hline & Sweden & 53.1 & 38.7 & 1.1 & & & 3.3 \\
\hline & USA & & 100.0 & & & & \\
\hline \multirow{5}{*}{$\begin{array}{l}\text { Non- } \\
\text { OECD }\end{array}$} & China & 242 & 537 & 95 & \multirow{5}{*}{$\begin{array}{l}4.4 \\
3.1\end{array}$} & \multirow{5}{*}{2.6} & 126 \\
\hline & Jordan & 63.5 & 17.0 & 8.1 & & & 4.3 \\
\hline & Pakistan & 17.7 & 76.9 & & & & 2.3 \\
\hline & Russia & & 100.0 & & & & \\
\hline & Thailand & 7.2 & 80.7 & 8.4 & & & 3.6 \\
\hline
\end{tabular}

Note: 1. "Alternative investments" refer to "private equity" for Canada and Ireland, while that for Korea and New Zealand refers to various alternative asset classes. 2. Data for Japan refers to the GPIF, while that for China refers to the National Social Security Fund. 3. The Thailand data refers to the year of 2005.

Source: National sources and OECD.

Information on objectives and asset allocations is more readily available for OECD PPRFs, though there are differences between funds in this respect. For most of the countries for which data are available, bonds and equities are the largest components in PPRFs portfolios (see 
Table 3). For example, as of 2007 France's FRR allocated $64.5 \%$ of its total assets to equities and 33.5\% to bonds, while the remaining was invested in cash $(1.2 \%)$ and other assets $(0.8 \%)$. At the extreme, PPRFs in Spain and the USA invested all assets in short-term assets and bonds. For the US Trust Fund, such conservative investment strategy is mandated in the relevant legislation.

Over time, there is a trend of increased allocation to equities and declining bond allocations in some countries. For example, equities accounted for $15.6 \%$ of the Canada Pension Plan assets, while bonds accounted for $63.0 \%$ in 2001. In 2007, these two figures were $57.9 \%$ and $28.3 \%$, respectively. A similar trend was observed in France and Portugal.

Generally speaking, because of its low returns, cash and its equivalent do not account for a significant share of the PPRF portfolios, except for Denmark.

In contrast, recently there has been an increased exposure to high yield, alternative assets, e.g. private equity. This trend is driven by the perceived low correlation between alternative and traditional asset classes and pressure on PPRFs to beat market benchmarks (so-called "beta") and seek higher "alpha" via active management. In most cases, active management is delegated to professional fund managers, though a few PPRFs (e.g. Canada's) carry out such investments in-house. Alternative investments accounted for $2.5 \%$ of the Korean National Pension Service funds as of 2007. Meanwhile, a major increase in the alternative asset allocation was implemented by the New Zealand Superannuation Fund (10.8\% in 2007, from $0.5 \%$ in 2005).

Some PPRFs are also increasing their allocation to foreign assets, though this information is not readily available for some funds. For the countries where statistics are available, the trend has been towards rapid increases in overseas investment. Examples include the $34.6 \%$ overseas investment of Irish PPRFs, ${ }^{3}$ and $75.3 \%$ overseas investment of New Zealand's Superannuation Fund in 2006. France's FRR started to invest in foreign assets (defined as assets denominated in non-Euro currencies) in 2004, with $5.1 \%$ of total assets, and this increased to $34.8 \%$ by 2007 . Foreign assets accounted for only $0.3 \%$ of Korea's NPF in 2002, but this increased to $10.8 \%$ in 2007. In Japan, foreign assets accounted for a large share and were on a steady rise, from $19.4 \%$ of the total portfolio in 2001 to $25.5 \%$ in 2006.

\section{Global financial stability issues}

Financial stability issues often come from two broad sources:

1. Excessive liquidity creation reflected in asset price inflation, and the encouragement of low interest rates and leverage.

2. Excessive concentrations of investments in particular securities.

\section{(1) Liquidity}

The creation of excessive global liquidity can cause asset bubbles. Fixed exchange rates in the face of capital inflows lead to foreign exchange accumulation and, if impossible to fully sterilise, easier domestic monetary conditions. This can contribute to local asset bubbles. The global investment of the reserves may affect prices in other financial markets.

\footnotetext{
${ }^{3}$ Note that for PPRFs in France and Ireland foreign investments refer to those investments in assets outside the euro area or denominated at non-euro currencies.
} 
The staggering growth of global reserves since the late 1990's is shown in Figure 3. Similar episodes have occurred during weak dollar periods in the past when Japan was the main driver. China has been a more consistent accumulator since the mid 1990s devaluation, and currently has USD 1.5 trillion of the (above) USD 5 trillion total. In periods of USD weakness Japan has carried out massive interventions, as can be seen from the chart. While Japan has huge holdings of foreign reserves, it has now been eclipsed by China as the major holder.

Rapid reserve accumulation has contributed to asset price pressures.

Foreign exchange intervention by central banks is typically carried out in US dollars and invested in US Treasury securities. This has served to keep US bond yields abnormally low relative to short rates, hence influencing other rates (e.g. mortgages at the fixed rate end) and the cost of capital more generally. This, in turn, influences leverage and asset prices through that channel.

Figure 3. Global USD reserves and contributions

Chinese intervention now dominates

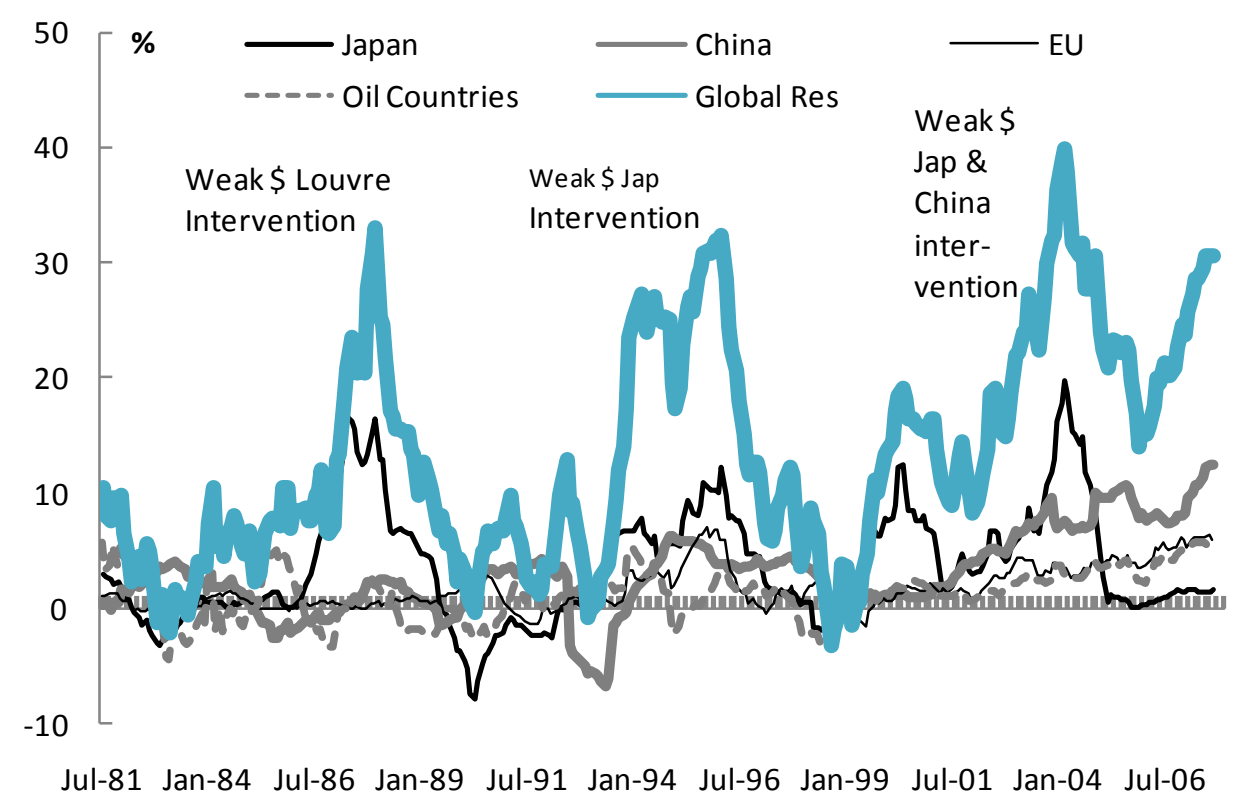

Source: Thomson Financial Datastream and OECD.

The growth of global reserves and China's stock market are shown in Figure 4. The mechanism here is that when risk taking rises, investors buy into emerging markets creating capital inflow into countries like China that fix or quasi fix their exchange rate. This eases monetary policy and contributes to stock market booms. 
Figure 4. Global Reserves and China's Stock Market

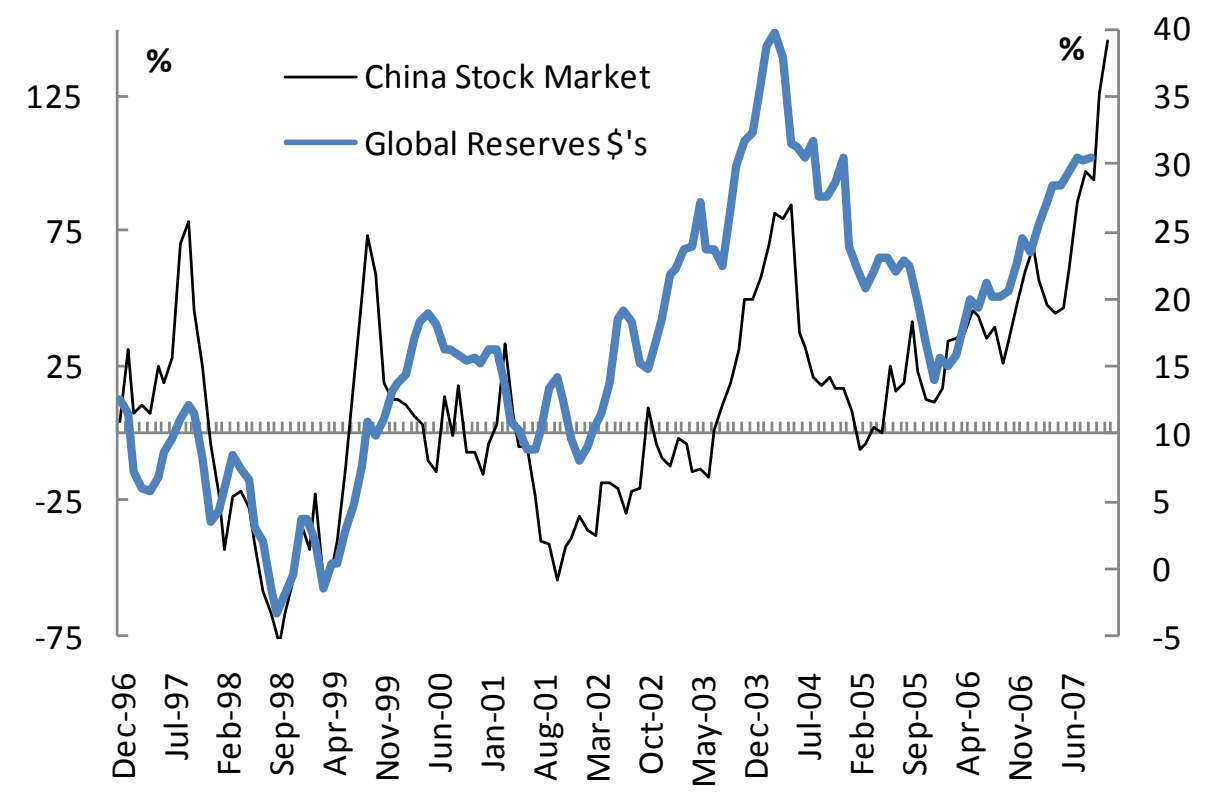

Source: IBES, Thomson Financial Datastream.

The growth rates of global reserves and of private equity deals are shown in Figure 5. Private equity has been in a bubble until recently.

Figure 5. Global liquidity and private equity deals

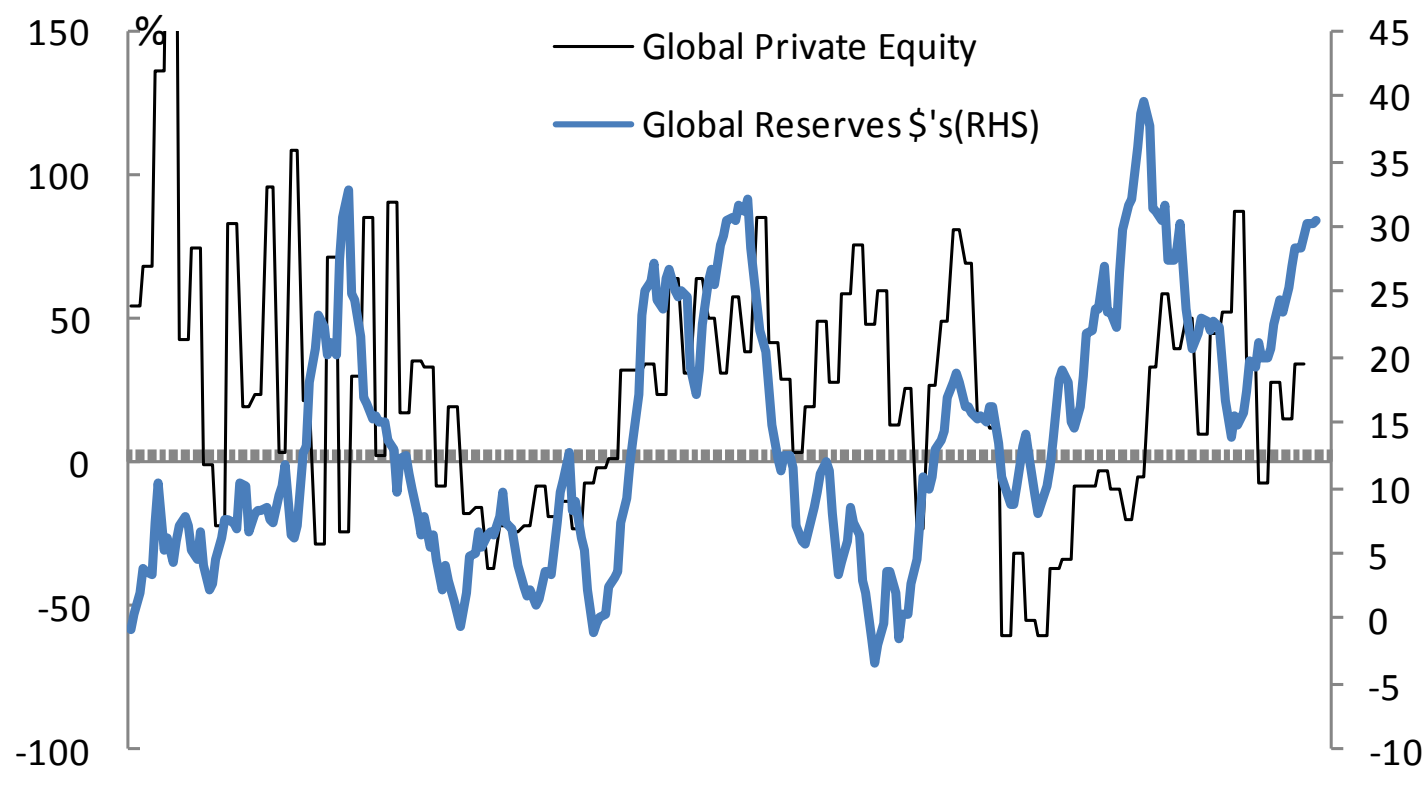

Jul-83 Jan-86 Jul-88 Jan-91 Jul-93 Jan-96 Jul-98 Jan-01 Jul-03 Jan-06

Source: Thomson Financial Datastream. 
The global reserves and a commodity price index constructed by the Reserve Bank of Australia (with a heavy weighting to materials used by China - energy, base metals, bulks) is shown in Figure 6. This is one of the bubbles that commodity funds have invested in. The hedge fund Amaranth had difficulties with respect to this bubble.

Figure 6. Global liquidity and commodity prices

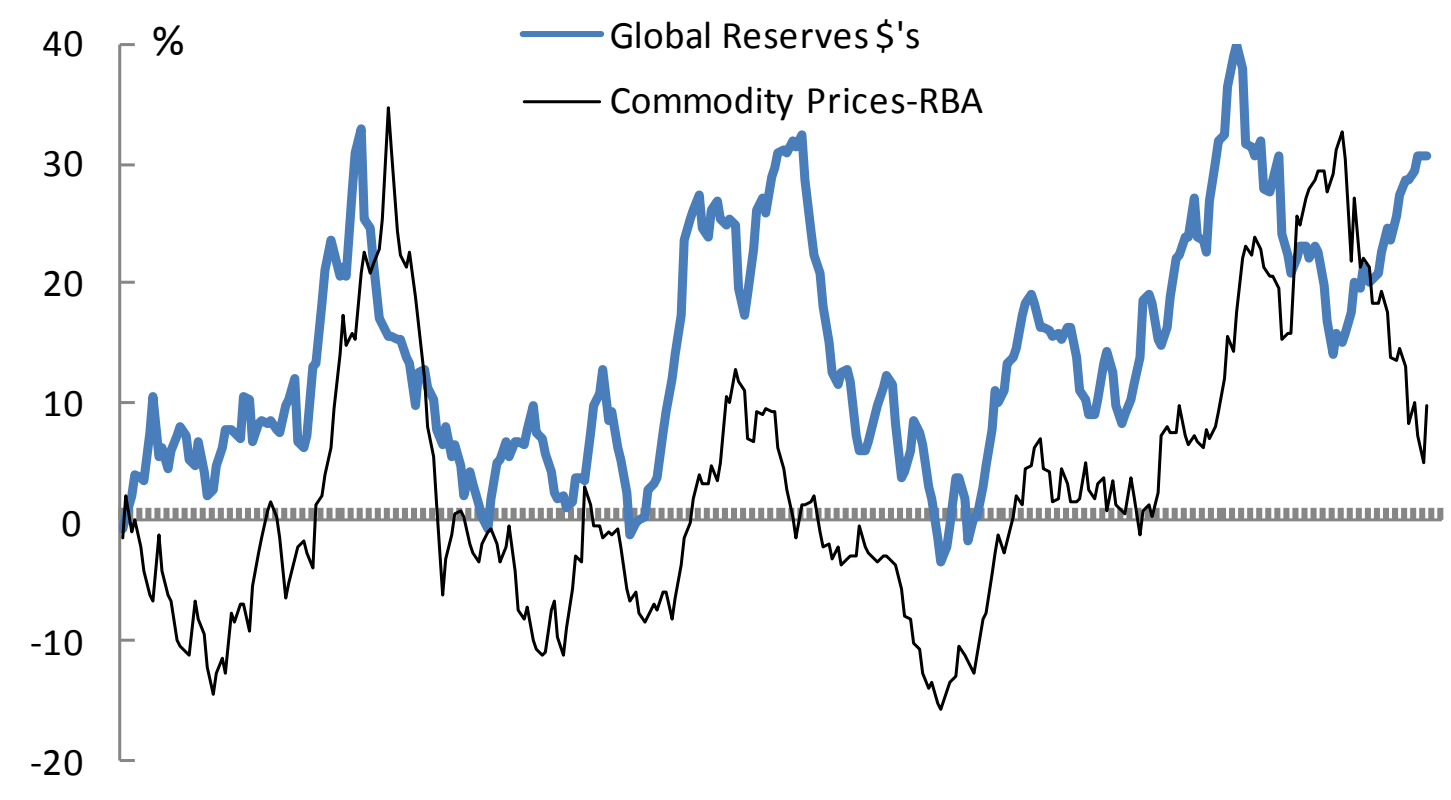

Jul-83 Jan-86 Jul-88 Jan-91 Jul-93 Jan-96 Jul-98 Jan-01 Jul-03 Jan-06

Source: Thomson Financial Datastream.

While foreign exchange reserve accumulation can create liquidity, this is not the case for SWF's. If a part of the USD foreign exchange reserves is transferred to a SWF, the central bank gets a credit and the SWF invests the reserves. There are indirect and second round effects, but no primary liquidity is created. If the SWF switches out of dollars into another currency, there will be an exchange rate impact (one reason why China can't really do this). If it switches out of one asset like a Treasury security to another one like an equity stock, there will be an asset price impact. Given the large size of some SWFs, changes in the strategic asset allocation, such as a shift from bonds to equities, could have a significant impact on the relative prices of these two asset classes. The price impact will also vary depending on whether the changes in portfolio allocation are carried out via new fund inflows (as is the case during periods of rapid asset accumulation, like the one we are going through) rather than the sale of existing assets. Stronger price effects can be expected once the growth rate of the funds slows down and changes in the investment policy can no longer be implemented solely by shifting inflows.

If a SWF provides capital to a private equity company, like Blackstone, the latter may lever this amount at the low global cost of capital (where the carry trade and other forces are at play). If they invest in smaller emerging markets which are less liquid they might increase volatility. But there are much bigger pools of capital in the West which will have exactly the same effects.

\section{(2) Excess Concentration}

SWFs provide mechanisms for breaking up concentrations of portfolios that increase risk. 
USD 1.5 trillion of Chinese reserves invested mainly in the US Treasury market distorts the yield curve in the US, and sudden changes could lead to USD and yield effects that could hurt (certainly) China and possibly the USA. By shifting assets to SWFs, the foreign exchange reserve concentration is reduced.

\section{Figure 7. Foreign holdings of US Treasury securities}

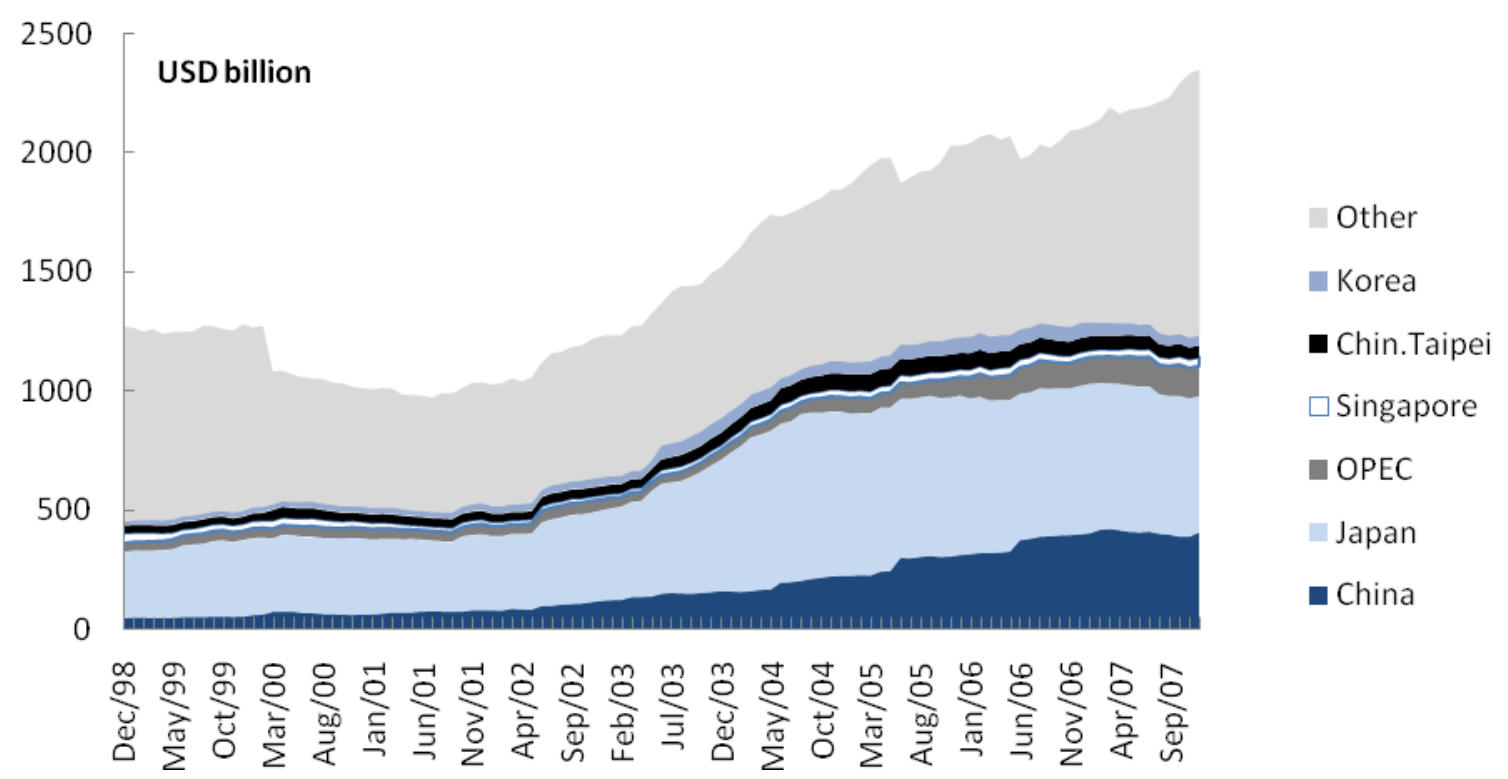

Source: Thomson Financial Datastream.

The official holdings of US Treasury Securities by some foreign governments are shown in Figure 7. The rising trend has been driven by Japanese and Chinese foreign exchange intervention policies. In this context it is also very clear that Singapore and OPEC, both of which are associated with the largest SWFs, and by some considerable margin, have very little holdings of US Treasury Securities. In other words, SWFs invest in a much more diversified way and do not concentrate their holdings in US Treasury Securities.

Many SWFs also hire external managers as a part of normal style diversification. Investing in equities in Western countries requires 'buying' experienced in-house teams, or outsourcing to western funds management firms, private equity companies and hedge funds. Once again, these structures and strategies are diversifying.

\section{(3) Governance}

To the extent that commercial considerations allow, clear corporate governance and full accountability are important for all public funds. Similar issues apply to both SWFs and PPRFs. PPRFs appear to have better transparency in these areas, and this probably follows from the clearer mandate and the fiduciary and pensioner ownership considerations that have become a part of the generally accepted wisdom in the pension area. Where these lines should be drawn for SWFs is less clear.

The clearer mandate of PPRFs stems from their founding purpose, which is to meet pension benefits. As a result, some PPRFs have specific investment return targets and concomitant investment strategies that have been designed on purely financial grounds. In particular, PPRFs try to achieve a rate of return that 
will help maintain the actuarial balance of the public pension system. In contrast, most SWFs have diffuse investment objectives, which can expose them to manipulation for political purposes.

Another difference with most SWFs is that many PPRFs, at least those of the sovereign type, are governed by boards that have been selected according to strict criteria of knowledge and professional experience in financial matters. The governing body of an PPRF of the sovereign type is typically either an independent committee (like the National Pensions Reserve Fund Commission in Ireland) or the highest organ of an independent legal entity that is exclusively responsible for the management of the reserve fund (like the Board of the Guardians of New Zealand Superannuation). One of the strictest eligibility requirements for board members is in place in New Zealand, where all board members must have experience, training and expertise in investment management.

Some public pension reserve funds, like the Canada Pension Plan reserve fund, are even operated by private sector management entities (the CPP Investment Board) and led by a board of professionals independent of government. The board approves investment policies and makes critical operational decisions, such as the hiring of the president and chief executive officer and the setting of executive compensation. Such governance structures ensure a high degree of protection against political interference in the management of the reserve fund.

While operating at arm's length from government, many PPRFs are subject to rigorous accountability requirements. Accountability is primarily exercised via strict disclosure requirement and oversight by relevant authority. PPRFs are required to publish an annual report, to have their accounts audited by an independent external audit firm (or in some cases the public audit office) and to provide regular and timely information on their website.

Disclosure is a particularly sensitive topic for both SWFs and PPRFs. Commercial considerations argue against detailed disclosure of investments in both SWFs and PPRFs. At the same time, there is a need to promote the transparency of the funds' investment policy. Public disclosure of asset allocation and investment performance at sufficiently long intervals (e.g. one year) and with prudent delays (a few months) can help meeting the goal of transparency without jeopardising the fund's confidentiality regarding some aspects of its investment management.

In conclusion, lessons can be learnt from existing PPRFs in OECD countries for the debate on the design, operation and role of SWFs in the global financial system. 